\title{
Effects of Non- Performing Loans on Economic Growth Evidence from four African countries: (Ghana, Nigeria, South Africa and Kenya)
}

Asiedu Michael*, Blessing Amos Atakli

Zhongnan University of Economics and Law (ZUEL) - Wuhan, China

DOI: $10.36347 /$ sjebm.2020.v07i08.003

| Received: 07.07.2020 | Accepted: 24.07.2020 | Published: 13.08.2020

*Corresponding author: Asiedu Michael

Abstract

Review Article

The central focus of this study is to find out how non-performing banking loans affect economic growth in four major African economies since this could help in significant macro and micro policy directions in the countries under consideration. The study employed panel regression analysis and adopted random effect model to find the relationship between the key variables of interest; economic growth (GDP) and Non-performing loans accounting for the heterogeneity that exists among the countries; Ghana, Nigeria, South Africa and Kenya using data from the world bank data catalogue from the period 1999 to 2019. The study established that Non-performing loans (NPL) and Bank Liquidity Reserve to Bank Assets ratio (Banksliq) negatively and significantly affects economic growth however, Inflation negatively affects economic growth but statistically insignificant. The results from this study therefore constitute an important call on policy makers and managers of these economies to adhere strictly to the laws regulating their financial and banking sectors especially on the issues of NPL and Banksliq. The governments and monetary policy authorities in these respective countries must also collaborate actively with the financial sector players to monitor and improve the control of access to the limited investment funds. This is to say that access to investment capital should be based on market principles. Fiscal policy should also be carefully anchored with monetary policy to avoid inflationary pressure since it also exposes borrowers to default risk.

Keywords: GDP, Bank Liquidity Reserve to Bank Assets ratio (Banksliq), Inflation and Non-performing loans (NPLs).

Copyright @ 2020: This is an open-access article distributed under the terms of the Creative Commons Attribution license which permits unrestricted use, distribution, and reproduction in any medium for non-commercial use (NonCommercial, or CC-BY-NC) provided the original author and source are credited.

\section{INTRODUCTION}

Banks and other financial markets and institutions are considered the backbone of all modern economies for many reasons including the creation of credit, breaking of bulky transaction but above all the mobilisation of liquidity in all modern economies. This art of banking is done by channelling excess liquidity from people who the supply of loanable funds people excess demand for such funds at a price (interest rate). Reasoning is this direction suggests that banks actually the blood wires and blood banks for all modern societies. The operations in the banking system can be simplified as gathering funds from suppliers (savers) in the form of deposits and then channelling such to investors (borrowers) as investment funds.

Generally after adoption of the structural adjustment program (SAP) in 1983 and the economic recovery program (ERP) in 1986 most countries in subsahara Africa also adopted a number of reforms towards improving the efficient allocation of investments funds.
A loan is described as a nonperforming loan when it is overdue or it stays in default for several months or years beyond the official scheduled data. Such maybe attributed to economy wide or borrower specific misfortune, however it is just a sign of a borrower's inability to settle the debt. The persistence of such a situation becomes a burden for the borrower and the lender.

When the loan is secured; Bernanke et al., [1] found that the presence of a nonperforming loan, valuable collateral of the borrower get trapped which even makes it more problematic to access new investment funds. Meanwhile the lender will also have to address the cost of the nonperforming loan in the form of wind-down costs. Until the problem of the nonperforming loan is addressed, the creation of new investment capital is constrained. Kwan and Eisenbeis [2], concluded that the presence of nonperforming loan ratios does not only drain the balance sheets of banks but also on their profitability. Nonperforming loans restrict credit creation and supply, distorts credit 
allocation, weakens economic growth and market confidence.

\begin{abstract}
Inadequate investment capital and low liquidity, weak financial institutions, weak macroeconomic environment among African countries has given rise to high ratio of nonperforming loans. It is therefore only natural and important to ascertain what the effect of nonperforming loans could be and how best policy makers should react in the face of their weak financial systems.
\end{abstract}

The aim of this paper is to find out the effect of nonperforming loans ratio on economic growth in four (4) African countries (Ghana, Nigeria, South Africa, Kenya) using annual data obtained from world bank data catalogue and their respective central bank official websites from the year 1999 to 2019.

\section{LITERATURE REVIEW}

A clear understanding of the effect of nonperforming loans on economic growth is not only important for academia but also necessary for policy makers to design policy tools that will help reduce the rising levels of nonperforming loans in most countries. For instance in a study conducted by Ishfaq MA et al., [3], using annual data of Pakistan from 1998 to 2010; applied simple regression analysis and found a negative and statistically significant relationship between economic growth (GDP) and Non-performing loans. They also found a positive and significant relationship between non-performing loans and interest rate. The ultimate conclusion from their study was that nonperforming loans significantly hurt the economy of Pakistan and rigorous policies must be initiated to reduce it.

Using panel data and regression analysis, Baasi [4] conducted a study on four selected banks in Ghana with data spanning from 2006 to 2016; he found that non-performing loans negatively and significantly affected banks profitability using fixed effect model. In 2016 Balgova et al., [5] employed freshly collected data on non-performing loans analysed the impact nonperforming loans had on the economy. They employed matching analysis in three different situations. They established that a fall in non-performing loans did not have a clear positive medium-term effect on the economy. Meanwhile, for economies that enjoyed inflow of new investment capital experienced the fastest growth and countries that consciously make efforts to resolve non-performing loans do relatively better. However when the non-performing loans problem is not actively addressed, the performance of the economy suffers. In that case the economy is likely to sacrifice an annual growth rate in excess of 2 percent.

Asfaw et al., [6] in their study of the factors affecting non-performing loans in Ethiopia found that among other factors contributing to the size of nonperforming loans in Ethiopia include but not limited to the following; bad credit evaluation and monitoring. They also found that bad customer credit culture, inadequate understanding of the loan taker for the business activities they doing, fraudulent default and general misappropriation of the borrowed funds play very critical roles in the rising size of nonperforming loans in Ethiopia.

Beck et al., [7] also studied the macroeconomic factors influencing nonperforming loans by adopted a novel panel data set across 75 countries over a decade. Their findings according to estimates of their dynamic panel nonperforming loan ratios, exchange rate, economic growth (real GDP ${ }_{\text {growth }}$ ) lending rates and share prices were statistically significant.

Chimkono et al., [8] conducted a study using secondary data for the period 2008 to 2014 analysed the effect of non-performing loan ratio on commercial banks performance in the banking sector of Malawi by employing regression analysis and the technique of correlation research. Principal among their findings is fact that non-performing loans ratio and the other supporting variables such as average lending rates and cost efficiency ratios statistically and significantly affected the banking sector performance in Malawi. Ayunkuand and Uzochukw [9] found from a random effect model that non-performing loans significantly affected the performance of banks in Nigeria using either Tobin-Q or ROA using data on fourteen commercial banks from 2014 to 2019. in a related study conducted by Klein N [10] for the period 1998-2011 on non-performing loans in South-Eastern, Central and Eastern Europe; his investigation revealed that the size non-performing loans can be associated to economy wide factors and banks' specific conditions. However he found that bank specific factors had relative little explanatory power but concluded that the high levels of nonperforming loans faced by many countries in SouthEastern, Central and Eastern Europe negatively affects the rate of their economic recovery.

\section{Data Size and Source}

The data for this study covers four (4) African countries (Ghana, Nigeria, South Africa, Kenya) using annual data obtained from World Bank data catalogue and their respective central bank official websites from the year 1999 to 2019 .

\section{Methodology and Model Specification}

The main objective of this study being to investigate how nonperforming loans affects economic growth in four (4) African countries (Ghana, Nigeria, South Africa, Kenya), and mimics the panel data model used by Gizaw et al., [11] in their study of the impact of credit risk on profitability performance of Ethiopian commercial banks. To serve as control variables, annual inflation rate and bank liquidity reserve to bank assets 
ratio (BANKSLIQ) are added in this model. To overcome the problem of heteroskedasticity all the variable were made stationary after their first difference using the augmented dicky-fuller test.

$$
\begin{aligned}
& G D P=f(N P L, I N F L A T I O N, \text { BANKSLIQ }) \ldots \ldots \ldots \ldots \ldots \ldots \ldots \ldots \ldots \ldots \ldots \\
& G D P_{i}=\beta_{0}+\beta_{1} N_{P L}+\beta_{2} \text { INFLATION }_{i}+\beta_{3} \text { BANKSLIQ }_{i}+\varepsilon
\end{aligned}
$$

From equation (2), the measure of economic growth is gross domestic product $(G D P)$ which is the dependent variable and as independent variables are; $N P L$ as the nonperforming loan ratio, INFLATION is also the measure of the general rise in the annual price level of goods and services and BANKSLIQ is the bank liquidity reserve to bank assets ratio also known $\mathrm{s}$ the liquidity coverage ratio. $\beta_{0}$ is the intercept and $\beta_{1}, \beta_{2}, \beta_{3}$ are the slopes of the independent variables and $\varepsilon$ is the error term.

\section{Panel data Regression Model Specification}

The data can be analysed either using the fixed effect model or the Random effect model depending on the results from the Hausman test. However in this study, the Random effect model was adopted due to its efficiency and it is supported by the results from the Hausman test. By stating the pooled regression as:

$$
G D P_{i t}=\beta_{0}+\beta_{1} N P L_{i t}+\beta_{2} I N F L A T I O N_{i t}+\beta_{3} B A N K S L I Q_{i t}+U_{i t}
$$

According to Zappe and Winston [12], to ensure an unbiased and reliable estimates, the assumptions of the classical linear regression must hold.
Meaning that the error term must be normally and independently distributed.

The Random Effect model (REM) and Fixed Effect Model (FEM)

$$
G D P_{i t}=\alpha_{i}+\beta_{1} N P L_{i t}+\beta_{2} I N F L A T I O N_{i t}+\beta_{3} B A N K S L I Q_{i t}+U_{i t}
$$

The $\mathrm{i}$ in $\alpha_{i}$ is the cross-sectional units of the intercept values for each cross-sectional unit.

Table-1: Correlation Analysis

\begin{tabular}{|l|l|l|l|l|}
\hline Variable & GDP & Banksliq & Inflation & NPL \\
\hline GDP & 1 & & & \\
\hline Banksliq & -0.038571 & 1 & & \\
\hline Inflation & -0.304055 & 0.339161 & 1 & \\
\hline NPL & -0.546213 & 0.251416 & 0.537971 & 1 \\
\hline
\end{tabular}

The table above presents the correlation matrix of both the dependent variable (GDP) and the independent variables (Banksliq, Inflation NPL). The report indicates that there is a very weak and negative relationship between the dependent and independent variables. This means that the model is able to overcome the problem of multicollinearity. The relationship from nonperforming loans ratio (NPL) to the other independent variables is also weak but positive which meets expectations.

The results of the fixed effect and random effect models are presented below.

Table-2: Fixed Effect and Random Effect Model (GDP as dependent variable)

\begin{tabular}{|l|l|l|l|l|l|l|}
\hline Variable & Fixed effect & t-value & p-value & Random effect & t-value & p-value \\
\hline Banksliq & -0.162911 & -4.052249 & 0.0001 & -0.163911 & -4.053249 & 0.0041 \\
\hline Inflation & -0.015333 & -0.619627 & 0.5359 & -0.015433 & -0.620627 & 0.5659 \\
\hline NPL & -0.154691 & 5.819434 & 0.0000 & -0.155691 & -5.820434 & 0.0015 \\
\hline CONS & 0.100557 & 4.792883 & 0.0000 & 0.100657 & 4.793883 & 0.0060 \\
\hline DW-stat & 2.051559 & & & 2.051668 & & \\
\hline Hausman -test & & & & & & 0.9785 \\
\hline F-statistic & 11.62707 & & & 23.46979 & & \\
R $^{2}$ Rdj. & 0.176720 & & & 0.179720 & & \\
R $^{2}$ Ad & 0.169190 & & & 0.168190 & & \\
\hline
\end{tabular}

Tables-2 above reports the fixed effect model, random effect model and the Huasman test results based on 84 balanced observations pooled from four (4) African countries (Ghana, Nigeria, South African and
Kenya) for the period 1999 to 2019 using annual gross domestic product (GDP) as the dependent variable and inflation, nonperforming loan ratio (NPL) and bank liquidity reserve to bank assets ratio (Banksliq) serving 
as independent variables. From the results of the Hausman test; the random effect model is choosen over the fixed effect model since the probability value is above $5 \%$; the null hypothesis is therefore not rejected.

\section{DISCUSSION OF RESULTS}

From Table-2 above, the DW test statistic of 2.051559 means that the model suffers from no serial correlation. The $\mathrm{R}^{2}$ of $18 \%$ means that only $18 \%$ of the variation GDP is explained by the independent variables. Small as it may be, but this is quite understandable since the purpose is not to define what constitutes economic growth but to capture the effect of an important variable as nonperforming loans ratio (NPL) on GDP.

In addition, both nonperforming loans ratio (NPL) and bank liquidity reserve to bank assets ratio (Banksliq) are statistically significant below $1 \%$ and negatively affects the size of economic growth (GDP).

For instance for every unit increase in nonperforming loans ratio (NPL), economic growth (GDP) will decline by 0.154691 and for every unit increase in Banksliq economic growth (GDP) will decline by 0.162911 . The sign of the coefficient of inflation is negative however, it is not statistically significant. The results generally points that the level and degree of significance of nonperforming loans ratios in these four (4) selected African countries is very sensitive the size of their economies measured by their respective annual gross domestic product (GDP).

\section{CONCLUSION}

The aim of this paper was to ascertain the effect of nonperforming loans on the economic growth (GDP) of four (4) selected African countries (Ghana, Nigeria, South African and Kenya) even though there are some studies on how non-performing loans affect the profitability of banks in some countries very little is available at the macro level to measure such effect on non-performing loans on economic growth beyond one country in African using panel data. The motivation therefore was to fill this vacuum. The significance of the overall effect of nonperforming loan on the economy is very adverse and significant. Rigorous credit ratings and personal credit scores of bank clients will be an important mechanism for reducing credit default. Bank managers and boards are also encouraged to use advanced credit risk management methods to diversify their operations. The governments and monetary policy authorities in their respective countries must also collaborate actively with the financial sector players to monitor and improve the control of access to the limited investment funds. This is to say that access to investment capital should be based on efficient market principles. Fiscal policy should also be carefully anchored with monetary policy to avoid inflationary pressure since it exposes borrowers to default risk.

\section{REFERENCES}

1. Bernanke B, Gertler M, Gilchrist S. The Financial Accelerator in a Quantitative Business Cycle Framework, in J. Taylor and M. Woodford (eds.), Handbook of Macroeconomics. 1999; Volume I.

2. Kwan SH, Eisenbeis RA. An analysis of inefficiencies in banking. Journal of Banking \& Finance. 1995;19(3-4):733-4.

3. Ahamad M, Guohui W, Ali R, Rehman R. NonPerforming Loans and Economic Growth. Journal of Economics, Business and Management. 2016;3:584-6.

4. Nyarko-Baasi M. Effects of Non-Performing Loans on the Profitability of Commercial Banks-A Case of some Selected Banks on the Ghana Stock Exchange. Global Journal of Management and Business Research. 2018 Mar 30.

5. Balgova M, Nies M, Plekhanov A. The economic impact of reducing non-performing loans. JEL, 2016; G21, G33, O40.

6. Asfaw A. Standard operating protocol for yam variety performance evaluation trial. 2016.

7. Beck R, Jakubik P, Piloiu A. Non-performing loans: What matters in addition to the economic cycle?. European Central Bank Working Paper 1515. 2013.

8. Chimkono EE, Muturi W, Njeru A. Effect of nonperforming loans and other factors on performance of commercial banks in Malawi. International Journal of Economics, Commerce and Management. 2016;4(2):549-63.

9. Ayunku PE, Uzochukwu A. Credit Management and Issues of Bad Debts: An Empirical Study of Listed Deposit Banks in Nigeria. Asian Journal of Economics, Business and Accounting. 2020 Mar 25:32-49.

10. Klein N. Non-Performing Loans in CESEE: Determinants and Impact on Macroeconomic Performance, IMF Working Paper, WP/13/72. 2013.

11. Gizaw M, Kebede M, Selvaraj S. The impact of credit risk on profitability performance of commercial banks in Ethiopia. African Journal of Business Management. 2015 Jan 28;9(2):59-66.

12. Zappe C, Albright SC, Winston WL. Data Analytics, Optimization and Simulation Modeling. 2011. 